\title{
Pengaruh Ethyl Methane Sulphonate (EMS) terhadap Morfologi Akar Kecambah Padi (Oryza sativa) Varietas Lallodo
}

\author{
Retty Asti Ogtavia Pratiwi dan Dini Ermavitalini \\ Departemen Biologi, Fakultas Sains, Institut Teknologi Sepuluh Nopember (ITS) \\ e-mail:dinierma@bio.its.ac.id
}

\begin{abstract}
Abstrak-Padi (Oryza sativa L.) merupakan tanaman pangan pokok lebih dari separuh penduduk dunia. Padi varietas Lallodo merupakan padi lokal dataran tinggi Toraja dengan nilai produksi gabah giling tertinggi. Salah satu upaya mendapatkan varietas unggul demi memenuhi kebutuhan pangan adalah induksi mutagen kimia, salah satunya Ethyl Methane Sulphonate (EMS). Tujuan dari penelitian ini adalah untuk mempelajari efek EMS pada morfologi akar. Parameter yang diamati pada penelitian ini adalah daya kecambah, panjang akar dan bentuk rambut akar kecambah padi Lallodo yang dipapar dengan larutan EMS pada konsentrasi $0 \% ; 0.25 \% ; 0.5 \% ; 0.75 \% ; 1 \%$; $1.25 \% ; 1.5 \%$, dan $2 \%$. Selanjutnya nilai daya kecambah dan panjang akar dianalisis dengan menggunakan ANOVA oneway dengan dilanjutkan uji Duncan. Hasil penelitian menunjukkan bahwa perlakuan EMS berpengaruh terhadap panjang akar kecambah padi dimana perlakuan EMS 0\%; 0,25\%; dan 0,50\% mempengaruhi panjang akar secara tidak signifikan. Perlakuan EMS juga berpengaruh pada daya kecambah pada hari 1 hingga 3, tetapi tidak berpengaruh pada daya kecambah hari 4 . Pengamatan visual morfologi rambut akar dengan mikroskop dan SEM (Scanning Electron Microscope) menunjukkan bahwa semakin tinggi konsentrasi EMS maka rambut akar semakin pendek dan kerapatannya semakin jarang.
\end{abstract}

Kata Kunci-EMS, Padi, Rambut Akar, var. Lallodo.

\section{PENDAHULUAN}

$\mathrm{T}$ ANAMAN padi (Oryza sativa L.) merupakan tanaman pangan penting yang telah menjadi makanan pokok lebih dari setengah penduduk dunia. Di Indonesia, padi merupakan komoditas utama dalam menyokong pangan masyarakat. Indonesia sebagai negara dengan jumlah penduduk yang besar menghadapi tantangan dalam memenuhi kebutuhan pangan penduduk. Oleh karena itu, kebijakan ketahanan pangan menjadi fokus utama dalam pembangunan pertanian. Kebutuhan akan beras terus meningkat seiring dengan laju pertumbuhan penduduk yang lebih cepat dari pertumbuhan produksi pangan yang tersedia[1].

Padi varietas Lallodo merupakan salah satu padi lokal dataran tinggi khas Tanah Torajayang memiliki nilai produksi gabah kering giling tertinggi dengan usia panen 155,4 hari [2]. Padi varietas ini mengandung pigmen paling baik dari padi putih, warna pada perikarpnya, aleuron, dan endospermnya seragam yaitu merah, biru, dan ungu pekat yang menunjukkan kandungan antosianin [3][4], dan [5]. Padi varietas Lallodo memiliki beberapa keunggulan diantaranya tekstur nasi yang pulen dengan kadar amilosa $0,260 \%$, kadar protein tinggi yaitu $10,635 \%$, kadar glukosa rendah yaitu $1,113 \%$, kadar serat tinggi yaitu 1,49\%, kandungan vitamin B yang tinggi, tahan terhadap OPT, serta kemampuan adaptasi yang baik pada dataran dengan ketinggian 700-2000 mdpl [2][6]. Namun padi hitam varietas Lallodo memiliki umur panen lebih lama yakni \pm 155 hari, dibandingkan dengan varietas padi hitam lainnya seperti pae Ambo dan melik hitam (umur panen \pm 130 dan 120 hari) [2][7]. Perbedaan usia panen dipengaruhi oleh berbedanya kemampuan penyerapan nutrisi yang dibutuhkan untuk memproduksi biji [8].

Salah satu organ yang berperan penting dalam penyerapan nutrisi adalah akar. Pada permukaan akar terdapat rambut akar yang merupakan sel epidermis khusus dengan luas permukaan besar yang terpapar langsung dengan tanah dam berfungsi dalam penyerapan hara dan mineral [9][10]. Semakin banyak rambut akar maka luas permukaan akar akan semakin besar dan memungkinkan tumbuhan untuk menjangkau air dan hara mineral di tempat yang jauh dari tumbuhan tersebut tumbuh. Dengan demikian pertumbuhan suatu tanaman diharapkan dapat mengalami peningkatan jika terdapat peningkatan pertumbuhan rambut akar.

Senyawa EMS merupakan senyawa alkil yang mengubah guanin menjadi 7-etilguanin yang berpasangan dengan timin dan banyak digunakan untuk menuningkatkan keanekaragaman genetik tanaman [11][12]. Penelitian mutasi pada rambut akar tanaman padi dengan menggunakan EMS (Ethylene Methane Sulfonat) telah dilakukan oleh [13], dan menunjukkan terjadi pengurangan panjang dan kerapatan rambut akar. Namun pada penelitian tersebut belum dapat ditentukan konsentrasi EMS manakah yang bersifat menguntungkan dengan meningkatkan jumlah rambut akar tanaman padi. Berdasarkan uraian di atas, maka penelitian ini akan melakukan uji pemberian EMS pada berbagai variaasi konsentrasi terhadap bentuk dan jumlah rambut akar kecambah padi varietas Lallodo.

\section{METODE PENELITIAN}

\section{A. Waktu dan Tempat Penelitian}

Penelitian ini dilaksanakan pada bulan Desember 2018 hingga bulan Januari 2019 di Laboratorium Biosains dan Teknologi Tumbuhan Departemen Biologi Fakultas Sains, Institut Teknologi Sepuluh Nopember Surabaya. 


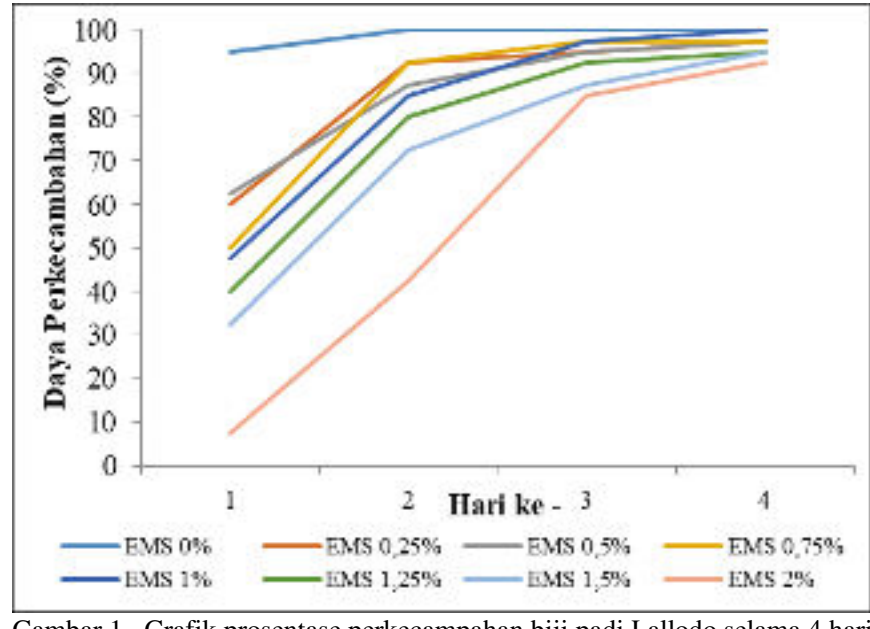

Gambar 1. Grafik prosentase perkecampahan biji padi Lallodo selama 4 hari.

\section{A. Persiapan Benih}

Benih yang akan digunakan sebagai bahan penelitian dipilih terlebih dahulu dengan cara direndam didalam air. Apabila benih tenggelam maka benih tersebut yang akan digunakan. Benih dicuci dengan deterjen (merk Sunlight) dan direndam selama 15 menit, Pencucian ini digunakan untk membersihkan kotoran pada benih. Kemudian benih dibilas dengan akuades. Setelah itu benih direndam dalam fungisida $2 \%$ (merk DuPont Acapela system 280 SC) selama 15 menit. Selanjutnya benih ditiriskan dan dicuci dengan akuades steril untuk menghilangkan sisa larutan fungisida [14]. Pada bilasan terakhir, benih direndam dengan akuades selama 24 jam untuk meningkatkan kemampuan imbibisi benih.

\section{B. Perendaman Biji Padi dengan EMS}

Benih padi direndam ke dalam $100 \mathrm{ml}$ aquadest di dalam gelas beker pada suhu ruangan selama $24 \mathrm{jam}$. Benih yang telah direndam dikeringkan diatas kertas saring. Benih yang digunakan untuk kontrol hanya direndam dengan akuades. Sedangkan pada perlakuan menggunakan EMS, benih direndam dalam $50 \mathrm{ml}$ EMS konsentrasi $0.25 \%$; $0.5 \%$; $0.75 \% ; 1 \% ; 1.25 \% ; 1.5 \%$ dan $2 \%$ selama 4 jam. Benih yang telah direndam kemudian dibilas dengan akuades steril untuk menghilangkan sisa mutagen [15] dengan modifikasi.

\section{Perkecambahan Benih Padi}

Perkecambahan dilakukan dengan menyemai benih padi yang telah direndam di atas kertas saring yang telah dibasahi dengan aquades steril di dalam cawan petri. Pada tiap cawan petri diletakkan 10 benih padi. Perkecambahan dilaksanakan sampai akar muncul. Pengamatan pada akar dilakukan pada akar yang berusia 4 hari dihitung dari hari pertama munculnya akar. Banyaknya biji yang berkecambah dihitung setiap harinya. Pada hari keempat panjang akar kecambah dihitung dengan menggunakan penggaris.

\section{Pengamatan menggunakan SEM (Scanning Electron Microscope)}

Bagian akar umur 4 hari yang akan diamati secara hati hati dipindah dengan menggunakan pinset dari media

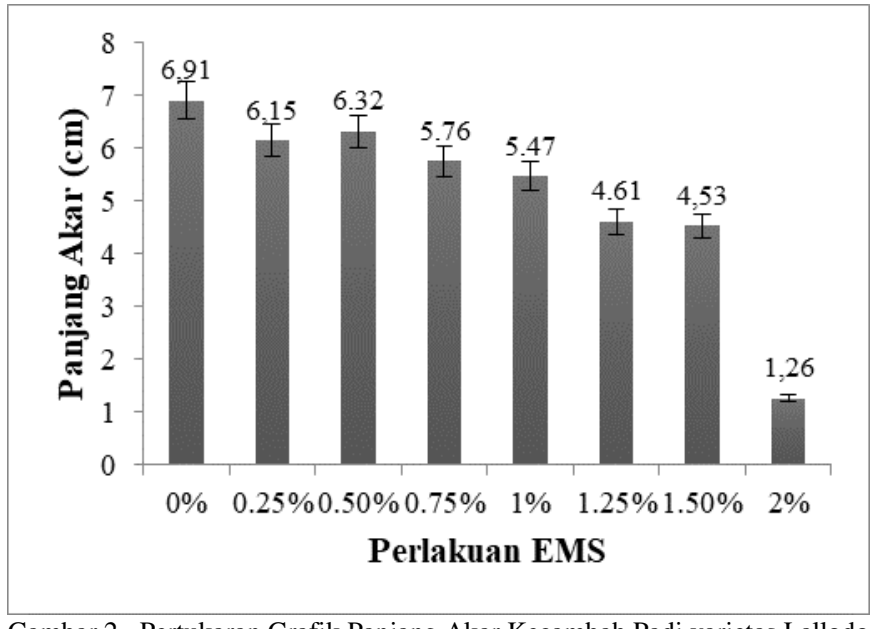

Gambar 2. Pertukaran Grafik Panjang Akar Kecambah Padi varietas Lallodo.

perkecambahan untuk segera diletakkan dalam larutan glutaraldehyde $2.5 \%$ selama semalam dalam suhu $4^{\circ} \mathrm{C}$ sampai dengan dilakukan analisa menggunakaan SEM. Pada saat dilakukan analisa SEM, akar apikal dipotong sepanjang $0.5 \mathrm{~cm}$ yang terdiri dari bagian ujung akar, zona pemanjangan dan zona rambut akar dewasa. Pada sampel dilakukan dehidrasi pada seri etanol bertingkat dengan konsentrasi 50, 70, 95 dan $100 \%$. Selanjutnya sampel dilapisi oleh Pt dan $2 \mathrm{~nm}$ lapisan karbon. Selanjutnya sampel siap dilakukan pengamatan dengan SEM type Zeiss 1555 VP-FESEM dengan sinyal sekunder electron sebesar $5 \mathrm{Kv}$. Sebanyak 3 area pengamatan dilakukan pada masing masing perlakuan [16].

\section{E. Analisis Data}

Penelitian ini dianalisa secara deskriptif dan kuantitatif. Analisa secara dekriptif memberikan deskripsi pengamatan SEM pada panjang dan kerapatan rambut akar masing masing perlakuan konsentrasi EMS. Sedangkan analisa kuantitatif dilakukan dengan menggunakan Rancangan Acak Lengkap (RAL) terhadap persentase daya kecambah dan panjang akar. RAL terdiri dari satu faktor yakni konsentrasi mutagen EMS (8 taraf; $0 \%, 0.25 \% ; 0.5 \% ; 0.75 \% ; 1 \% ; 1.25 \% ; 1.5 \%$ dan $2 \%)$. Pengulangan dalam penelitian ini dilakukan sebanyak 4 kali, dimana setiap ulangan terdiri dari 10 benih padi sehingga didapatkan 32 unit percobaan dengan total 320 benih biji uji.

Data panjang dan jumlah rambut akar kecambah padi dianalisis dengan menggunakan ANOVA Oneway taraf kepercayaan 95\%. Analisis dilakukan dengan menggunakan software SPSS.

Adapun hipotesa analisa sebagai berikut:

1. $\mathrm{H}_{0}$ : Tidak ada pengaruh penambahan EMS terhadap jumlah dan panjnag rambut akar kecambah benih padi (Oryzae sativa) varietas Lallodo

2. $\mathrm{H}_{1}$ : Ada pengaruh penambahan EMS terhadap jumlah dan panjang rambut akar kecambah benih padi (Oryzae sativa) varietas Lallodo

3. Jika $\mathrm{H}_{1}$ diterima maka dilanjutkan dengan uji Duncan dengan tingkat kesalahan 5\%. 


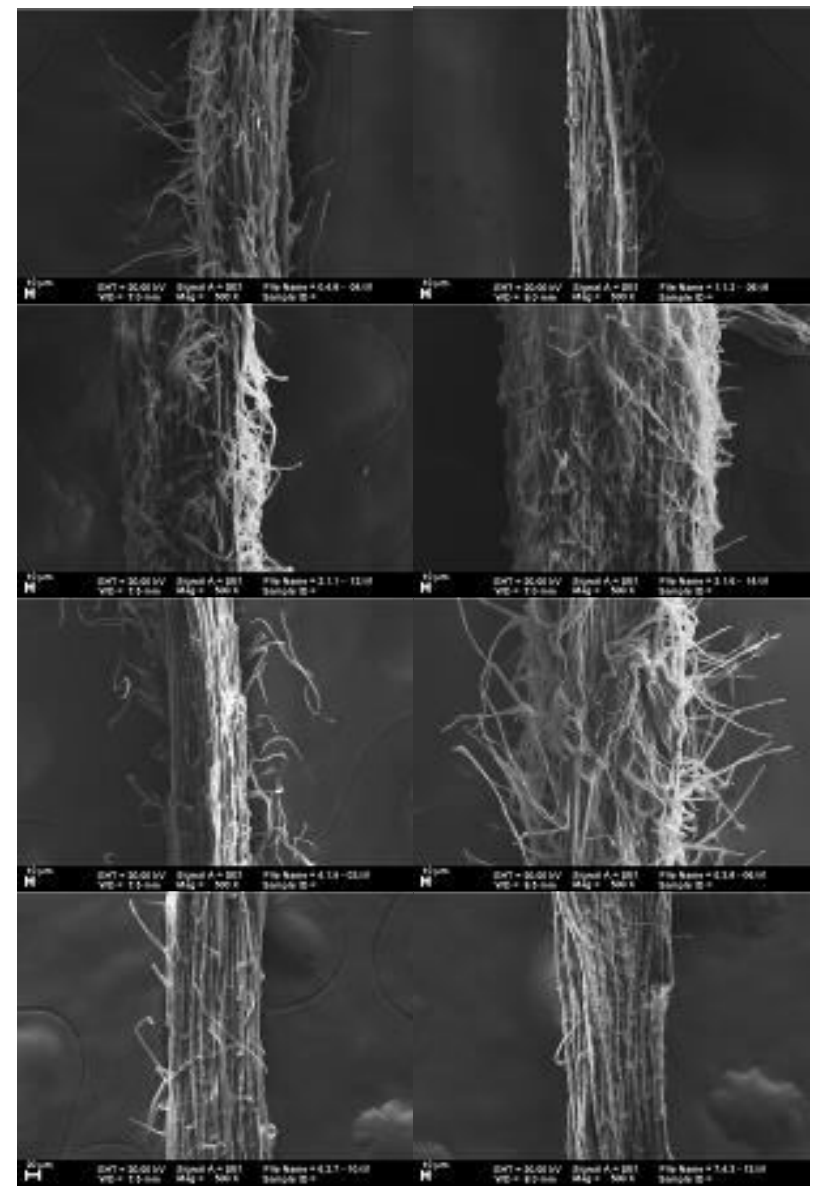

Gambar 3. Bentuk rambut akar kecambah padi Lallodo menggunakan SEM (a) EMS 0\% (b) EMS $0.25 \%$ (c) EMS 0.5\% (d) EMS 0.75\% (e) EMS 1\% (f) EMS $1.25 \%$ (g) EMS $1.5 \%$ dan (h) EMS 2\%. Perbesaran 500x

\section{HASIL DAN DISKUSI}

\section{A. Pengaruh Konsentrasi EMS terhadap Daya Kecambah Benih Padi Varietas Lallodo}

Data persentase perkecambahan pada Gambar 4.1 menunjukkan bahwa biji padi hitam Lallodo yang diberi perlakuan perendaman dengan EMS dengan konsentrasi 0.25\% hingga $2 \%$ memiliki prosentase perkecambahan diatas $90 \%$ pada hari keempat. Nilai prosentase perkecambahan tertinggi terdapat pada perlakuan kontrol (EMS 0\%) yaitu sebesar $100 \%$ yang dicapai pada hari kedua, sedangkan persentase terkecil pada hari keempat terdapat pada biji yang direndam dengan EMS konsentrasi 2\%. Secara umum jumlah biji yang berkecambah meningkat setiap harinya. Namun peningkatan persentase perkecambahan yang paling besar terjadi pada hari kedua dan ke tiga pada biji dengan perendaman EMS konsentrasi $>0.25 \%$.

Hasil statistik menggunakan ANOVA oneway menunjukkan bahwa daya kecambah menunjukkan nilai signifikansi sebesar $>0.05$ pada hari ke $1-3$, kecuali pada hari ke 4. Hal ini menunjukkan bahwa konsentrasi EMS berpengaruh signifikan terhadap daya kecambah padi. Hal ini didukung dari hasil uji lanjutan menggunakan uji Dunnet yang menunjukkan perlakuan EMS $1.5 \%$ dan $2 \%$ memiliki nilai signifikan $>0.05$ pada hari ke 1-3. Menurunnya kecepatan perkecambahan merupakan dampak dari pemberian mutagen pada proses metabolisme sel yang berdampak pada perubahan pada fisiologis sel [17]. Pada saat perkecambahan kelompok protein yang mengalami peningkatan regulasi adalah protein yang berhubungan dengan katabolisme [18]. Hasil penelitian [19], menyebutkan bahwa EMS dapat menurunkan aktivitas enzim $\alpha$-amilase pada saat perkecambahan padi hitam varietas Cempo Ireng. Penurunan aktivitas enzim $\alpha$-amilase dikarenakan adanya perubahan struktur pada sisi aktif yang menyerupai substrat. Enzim $\alpha$-amilase merupakan enzim yang berperan untuk memecah ikatan $\alpha-1,4$ glikosidik pada amilum sehingga dapat menghasilkan monomer glukosa [20]. Terganggunya aktivitas enzim amilase menyebabkan penyediaan energi untuk perkecambahan menjadi terganggu.

\section{B. Pengaruh Konsentrasi EMS Terhadap Panjang Akar Kecambah Padi varietas Lallodo}

Perlakuan EMS pada dosis rendah yakni EMS $0.25 \%$ dan $0.5 \%$ menunjukkan nilai rata-rata panjang akar sebesar 6,153 $\mathrm{cm}$ dan $6,320 \mathrm{~cm}$ (Gambar 2). Kedua konsentrasi EMS rendah tidak berbeda signifikan dengan panjang akar EMS kontrol (nilai sign > 0.05). Hal ini disebabkan EMS pada konsentrasi rendah merubah gen yang mempengaruhi biosintesis beberapa hormon pertumbuhan yang berakibat dalam pembelahan dan pemanjangan sel. Menurut hasil penelitian [21], menyatakan bahwa semakin rendah konsentrasi EMS yang digunakan maka EMS dapat berfungsi menjadi auksin. Panjang akar paling rendah ditunjukkan pada perlakuan EMS 2\% dengan rata-rata panjang akar $1.26 \mathrm{~cm}$. Hal ini disebabkan sifat racun EMS yang mengganggu fisiologis kecambah. Penurunan sifat kuantitatif tanaman seperti panjang akar disebabkan mutasi acak akibat aksi mutagen. EMS menyebabkan mutasi titik melalui transisi DNA, melalui perubahan pasangan basa nukleotida yang mengakibatkan perubahan asam amino [11].

\section{Pengaruh Konsentrasi EMS Terhadap Bentuk Rambut Akar Kecambah Padi varietas Lallodo}

Bentuk rambut akar pada pengamatan dibawah mikrokop menunjukkan hasil yang berbeda pada setiap perlakuan EMS. Perlakuan EMS konsentrasi 0.5\%; 0.75\%; 1\% dan 1.25\% secara visual menunjukkan bentuk rambut akar yang panjang dan lebih rapat dibandingkan kontrol. Berbeda dengan bentuk rambut akar pada perlakuan EMS $1.5 \%$ dan $2 \%$ secara visual bentuk rambut akarnya lebih pendek dan kerapatannya lebih jarang.

Menurut [21], semakin rendah konsentrasi EMS yang digunakan maka EMS dapat berfungsi menjadi auksin. Pendapat [22], juga menjelaskan bahwa penggunaan mutagen kimia dengan konsentrasi rendah dapat merangsang atau menstimulasi pertumbuhan tanaman dan menginduksi fisiologi tanaman. Peningkatan panjang akar dan kecambah diharapkan mampu meningkatkan daya serap hara untuk proses metabolisme dan fotosintesis [23].

\section{KESIMPULAN/RINGKASAN}

Hasil penelitian menunjukkan bahwa perlakuan EMS berpengaruh terhadap panjang akar kecambah padi dimana 
perlakuan EMS 0\%; 0,25\%; dan 0,50\% mempengaruhi panjang akar secara tidak signifikan. Perlakuan EMS juga berpengaruh pada daya kecambah pada hari 1, 2, dan 3 tetapi tidak berpengaruh pada daya kecambah hari keempat. Bentuk rambut akar diketahui dengan pengamatan mikroskop dan Scanning Electon Microscopy (SEM) dimana secara visual hasil menunjukkan bahwa semakin tinggi konsentrasi EMS maka bentuk rambut akar semakin pendek dan kerapatannya semakin jarang.

\section{DAFTAR PUSTAKA}

[1] F. A. Anggraini and N. A. Suryanto, "Sistem tanam dan umur bibit pada tanaman padi sawah (Oryza sativa L.) varietas inspasri 13," $J$. Produksi Tanam., vol. 1, no. 2, 2013.

[2] Y. Limbongan and F. Djufri., "Karakterisasi dan Observasi Lima Aksesi Padi Lokal Dataran Tinggi Toraja, Sulawesi Selatan," Bull. Plasma Nutfah, vol. 21, no. 2, pp. 61-70, 2015.

[3] D. Suardi and I. Ridwan., "Beras hitam, pangan berkhasiat yang belum populer," War. Penelit. dan Pengemb. Pertan., vol. 31, no. 2, pp. 9-10, 2009.

[4] T. Kristantini, P. Basunanda, R. H. Murti, Supriyanta, S. Widyayanti, and Sutarno., "Morphological of Genetic Relationships Among Black Rice Landraces from Yogyakarta and Surrounding Area," ARPN J. Agric. Biol. Sci., vol. 7, no. 12, pp. 982-987, 2012.

[5] R. Sa'adah, Supriyanta, and Subedjo, "Keanekaragaman warna gabah dan warna beras varietas lokal padi beras hitam (Oryza sativa L.) yang dibudidayakan oleh petani kabupaten Sleman, Bantul, dan Magelang,"Vegetalika, vol. 2, no. 3, pp. 13-20, 2003.

[6] Pusat Perindungan Varietas Tanaman, "Berita Resmi PVT Tanaman Padi Varietas Hitam Melik A3 No publikasi 34/BR/PVL/11/2016," 2016.

[7] Pusat Perindungan Varietas Tanaman, "Berita Resmi PVT Tanaman Padi Varietas Lallodo. No publikasi 54/BR/PVL/02/2014," 2014.

[8] H. Kim, O.-W. Kim, A. W. Ha, and S. Park., "Determination of Optimal Harvest Time of Chuchung Variety Green Rice $\mathbb{R}$ ) (Oryza sativa L.) with High Contents of GABA, $\gamma$-Oryzanol, and $\alpha$ Tocopherol," Preview Nutr. Food Sci., vol. 21, no. 2, pp. 97-103, 2016.

[9] N. Tanaka et al., "Characteristics of a root hair-less line of Arabidopsis thaliana under physiological stresses," J. Exp. Bot., vol. 65, no. 6, pp. 1497-1512, 2014.
[10] N. A. Campbell, J. B. Reece, and L. G. Mitchell., Biologi Edisi ke 5 Jilid 2. Jakarta: Erlangga, 2000.

[11] C. VL. Mutagenesis, "Investigating the process and processing the outcome for crop improvement," J. Curr. Sci., vol. 89, pp. 353359, 2005.

[12] M. Imelda, P. Deswina, S. Hartati, A. Estiati, and S. Atmowijoyo, "Chemical mutation by Ethyl Methane Sulfonate (EMS) for bunchy top virus resistence in Banana," Ann. Bogor., vol. 7, pp. 19-25, 2000

[13] L. Wang, B. Zhang, L. Jinrui, Y. Xiaoyu, and Z. Ren, "Ethyl Methane Sulphonate (EMS) - Mediated Mutagenesis of Cucumber ( Cucumis sativus )," Agicultural Sci., vol. 5, pp. 716-721, 2014.

[14] B. S. Putra and K. I. Purwani., "Pengaruh mutagen kimia EMS (Ethyl Methane Sulphonate) terhadap daya kecambah benih tanaman tembakau var. Marakot," J. Sains dan Seni POMITS, vol. 6, no. 2, pp. E89-E92, 2017.

[15] A. B. Talebi, A. B. Talebi, and B. Shahrokhifar., "Ethyl Methane Sulphonate (EMS) Induced Mutagenesis in Malaysian Rice (cv. MR219) for Lethal Dose Determination," Am. J. Plant Sci., vol. 2012, no. 3, pp. 1661-1665, 2012.

[16] C. Martin, J. Statton, D. Gleeson, and A. R. Siebers, "Low Light Availability Alters Root Exudation and Reduces Putative Beneficial Microorganisms in Seagrass Roots," Front. Microbiol., vol. 8, pp. $1-16,2018$.

[17] A. Sonavane., "Effects of EMS and SA on seed germination precentage in M1 generation of Psophocarpus tetragonolobus (L.) Dc," Int. J. Bioassays, vol. 5, no. 11, pp. 5056-5058, 2016.

[18] D. He, C. Han, and P. Yang, "Gene expression profile changes in germinating rice," J. Intregative Plant Biol., vol. 53, no. 10, pp. 835-844, 2011.

[19] N. Pramadhita, "Pengaruh Etil Metan Sulfonat (EMS) dan Giberelin Terhadap Perkecambahan Serta Pertumbuhan Awal Padi Hitam (Oryza sativa L. 'Cempo Ireng')," Yogyakarta, 2015.

[20] E. McMurry, Organic Chemistry with Biological Application. USA: Brooks/ Cole, 2011.

[21] W. Agung and Priyono, "Respon regenerasi in vitro eksplan sisik mikro Kerk Lily (Lilium longiflorum) terhadap Ethyl Methane Sulfonate (EMS)," Jurnal. Ilmu Dasar, vol. 3, no. 2, pp. 74-79, 2002.

[22] R. Potdukhe, "Effect of Physical and chemical mutagens in M1 generation in red gram (Cajanus cajan)," Nat. J. Pl. Improv., vol. 6, no. 2, pp. 108-111, 2004.

[23] S. Arous, M. Boussaid, and M. Marrakchi., "Plant regeneration from zygotic embryo hypocotyls of Tunisian chili (Capsicum annum L.)," J. Appl. Hort, vol. 3, pp. 17-22, 2001. 